\title{
Investigation on Retrofitting of Reinforced Concrete Beam with Glass Fiber and Banana Fiber Mat
}

\author{
M. Rajendran ${ }^{1, a^{*}}$, S. Sanjaygandhi ${ }^{1, b}$, V. Senthilkumar ${ }^{2, c}$ and \\ S. Ramakrishnan ${ }^{3, d}$ \\ 1Department of Civil Engineering, Bannari Amman Institute of Technology, \\ Sathyamangalam-638401, India \\ ${ }^{2}$ Department of Civil Engineering, Sri Shakthi Institute of Engineering \& Technology, \\ Coimbatore-641062, India \\ ${ }^{3}$ Department of Civil Engineering, Sri Krishna College of Engineering and Technology, \\ Coimbatore-641008, India \\ *arajendranm@bitsathy.ac.in, bsanjaygandhi.st19@bitsathy.ac.in, ccivilvsk@gmail.com, \\ dramakrishnans@skcet.ac.in
}

Keywords: Retrofitting, Reinforced Concrete Beam, Glass Fiber, Banana Fiber, Ultimate Load Carrying Capacity

\begin{abstract}
Concrete is the predominant material in the construction industry. To be sustainable, the old Reinforced Concrete (RC) buildings should be retrofitted, and the life of the building should be extended. Experimental study has been attempted to investigate the load carrying capacity of concrete beam strengthened with glass fiber and banana fiber mat. The primary aim of this study is to retrofit the RC beam specimen to enhance the load carrying capacity. All the beams were casted with the same grade of concrete (M30) and same structural detailing. Two-point symmetrical loading were given to the control beams to obtain load at initial crack and ultimate load. Then the beams other than control beams were loaded till it showes initial crack and then retrofitted with banana fiber and glass fiber bonded externally with resin. The retrofitted beams were tested for ultimate load performance. Load carrying capacity was higher for both retrofitting but the beam retrofitter with glass fiber showed significant improvement in the ultimate load carrying capacity.
\end{abstract}

\section{Introduction}

Reinforced concrete is one of the most important materials in the construction field. Concrete related structures are to be damaged due to several reasons after their life time. In such cases the damaged portion of the structures is difficult to replace because of financial issues and time duration. The alternative remedy for repairing the damaged structure is retrofitting instead of replacing the structure.

Retrofitting is all about the process of strengthening the older buildings, damaged structures such as heritage buildings, bridges etc., It lowers the risk of damage to an existing structure. Retrofitted specimen helps to minimize the further damage of the structure. This paper reports about the strengthening of reinforced concrete beam using glass fiber and banana fiber mat.

There are various types of glass fiber which differ only in the proportioning of their contents[1]. Synthetic fiber is added to the concrete mix to avoid the shrinkage cracking of plain concrete[2]. Concrete with self-curing agents would be a new development in the concrete construction industry[3]. Application of carbon fiber brings about very good improvement in strength but the failure is usually explosive in nature[4]. Melt spinning techniques are used in producing E-Glass fibers[5]. 
A comparative study on flexural strength of wrapped and unwrapped beams and found a higher ultimate load carrying capacity and initial crack load for wrapped beams compared to unwrapped beams[6]. Similar to the internal flexural steel reinforcement, the principal tensile fibers are oriented in the longitudinal axis of the beam[7]. The addition of polypropylene fibers to concrete reduces its unit weight while increasing its strength[8]. FRP sheets or plates are added to the tension face of the member for flexural strengthening[9].

Steel fiber reinforcement not only improves the material's hardness, impact and fatigue resistance, but it also improves the material's resistance against cracking[10]. Also, the weakness of plain concrete can be removed by inclusion of fibers in the mix[11]. Retrofitting with FRP sheets, especially GFRP sheets, was found to be the most suitable and cost-effective way to extend the service life of the beam[12]. The contribution of fibers in concrete towards flexural strength is smaller compared to the strength given by the rebar[13].

Various government bodies and academic institutions have consistently advocated the use of waste materials as an alternative construction material, such as fly ash, glass powder, and ground granular blast furnace slag (GGBS)[15].

There are various types of techniques to be followed for retrofitting the beam. Externally bonded glass fiber and banana fiber mat are used to retrofit the beam specimen. Uni-directional woven glass fiber sheet is utilized in current research and non-corrosive in nature.

Banana fiber is generally lignocelluloses material, consisting of helically wound cellulose micro fibers in amorphous matrix of lignin and hemi cellulose. Banana fibers have desirable mechanical properties due to their high cellulose content and low micro fibril angle. Lignin's are bound with hemicellulose and play an important role in lignocellulose materials' natural decay resistance.

In present investigation, M30 concrete grade is used. Mix design was done as per IS 10262: 2009 "Indian Standard Concrete Mix Proportioning - Guideline"[16]. Based on the above practice, a concrete proportion with a characteristics target compressive strength is designed. Experimental investigations have been carried out to find outthe enhancement of flexural strength of M30 grade concrete specimen. Thetests were conducted as per IScodalspecifications.

\section{Materials}

Cement, Fine and Coarse aggregate

Ordinary Portland Cement (OPC) of grade 53 was used in this study. Fine aggregate which only passes through $4.75 \mathrm{~mm}$ sieve was sieved and selected. Manufacturing sand ( $\mathrm{M}$ sand) derived from the granite stone quarry was used instead of natural river sand due to its scarcity. As far as coarse aggregate was concerned, 60 percent $20 \mathrm{~mm}$ aggregate and 40 percent $12 \mathrm{~mm}$ aggregate was used.

\section{Glass fiber and Banana fiber mat}

The glass fiber is an artificial thin material bonded with huge number of extremely fine fiber of glass (Refer with: Figure 1). Banana fiber is natural fiber obtained from pseudo stem of banana plant relatively with good mechanical properties (Refer with: Figure 1). The properties of glass fiber and banana fiber are given in the table 1. 


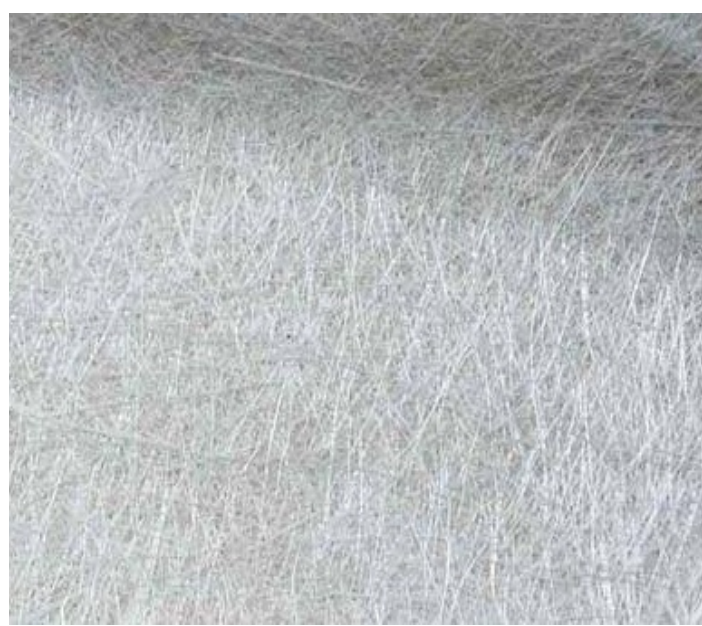

Figure 1. Glass fiber

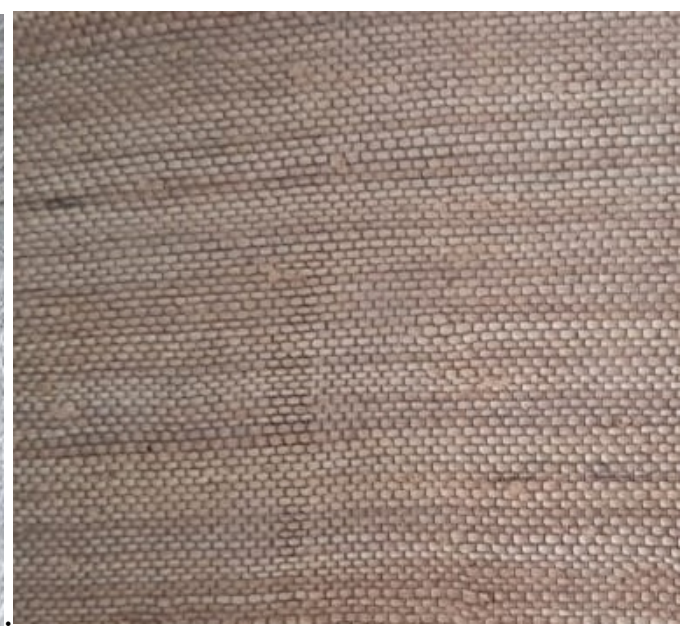

Figure 2.Banana fiber mat

Table 1. Properties of Glass fiber and Banana fiber

\begin{tabular}{|c|c|c|c|c|c|}
\hline \multicolumn{4}{|c|}{ Properties of glass fiber } & \multicolumn{2}{|c|}{ Properties of banana fiber } \\
\hline S.No & Test & $\begin{array}{l}\text { Standard } \\
\text { Value }\end{array}$ & $\begin{array}{l}\text { Observed } \\
\text { Value }\end{array}$ & Test & $\begin{array}{c}\text { Observed } \\
\text { Value }\end{array}$ \\
\hline 1 & Width $(\mathrm{cm})$ & $100 \pm 3$ & 100 & Tenacity & 29.98g/Denier \\
\hline 2 & $\begin{array}{l}\text { Moisture content } \\
(\% / \text { mass })\end{array}$ & $0.2 \max$ & 0.15 & Fineness & 17.15 \\
\hline 3 & $\begin{array}{l}\text { Loss on ignition } \\
(\% / \text { mass })\end{array}$ & $4.0 \pm 2.20$ & 4.05 & Moisture regain & $13.00 \%$ \\
\hline 4 & $\begin{array}{l}\text { Average } \\
\text { mass/unit are } \\
\left(\mathrm{g} / \mathrm{m}^{2}\right)\end{array}$ & $450 \pm 7$ & 440 & Elongation & 6.54 \\
\hline 5 & $\begin{array}{l}\%^{\text {age }} \text { variation in } \\
\text { mass per range }\end{array}$ & $<19$ & 8.90 & $\begin{array}{l}\text { Alcoben } \\
\text { extractives }\end{array}$ & $1.70 \%$ \\
\hline 6 & $\begin{array}{l}\text { Flexural strength } \\
\text { of laminate } \\
\text { Dry } \\
\text { Wet }\end{array}$ & $\begin{array}{l}180 \mathrm{mint} \\
135 \mathrm{mint}\end{array}$ & $\begin{array}{l}234 \\
195\end{array}$ & Total cellulose & $81.80 \%$ \\
\hline 7 & - & - & - & Alpha cellulose & $61.50 \%$ \\
\hline 8 & - & - & - & Residual gum & $41.90 \%$ \\
\hline 9 & - & - & - & Lignin & $15.00 \%$ \\
\hline
\end{tabular}

GP Resin

General purpose polyester resign is unsaturated chemical which was mixed together with cobalt, catalyst (MKEP) forms a polyester resin. Mix proportion proposed for this resin to retrofit the beam is $1 \mathrm{Kg}$ of resin added with $10 \mathrm{ml}$ of cobalt and $15 \mathrm{ml}$ of catalyst (Refer with: Figure 3 ). 


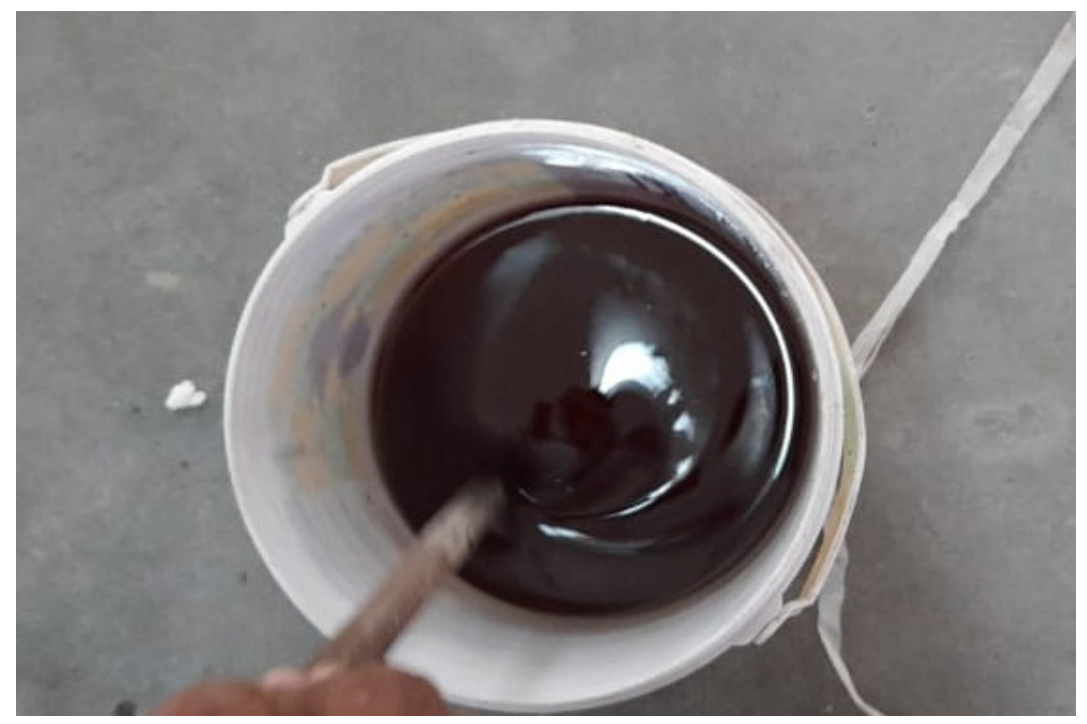

Figure 3. GP Resin

\section{MixDesignofM30GradeConcreteUsingIs10262:2009 [13].}

Mixproportion of conventional concrete of M30 grade.

$\begin{array}{lll}\text { Cement } & = & 497 \mathrm{~kg} / \mathrm{m}^{3} \\ \text { Fine aggregate } & = & 674 \mathrm{~kg} / \mathrm{m}^{3} \\ \text { Coarse aggregate } & = & 1099 \mathrm{~kg} / \mathrm{m}^{3} \\ \text { Water } & = & 197 \mathrm{~kg} / \mathrm{m}^{3}\end{array}$

\section{Casting of Beams}

Form work of mould and Beam casting

A wooden mould of dimension $150 \mathrm{~mm}$ wide, $250 \mathrm{~mm}$ deep and $1000 \mathrm{~mm}$ length was used to cast the beam.Generally, concrete's tensile strength is neglected. 2 numbers of $12 \mathrm{~mm}$ diameter Fe500 steel reinforcement were used in the tension and as well as compression zone. The stirrups will be $8 \mathrm{~mm}$ diameter provided at $150 \mathrm{~mm}$ center to center spacing for the entire length. The structural detailing is shown in figure 4.a and 4.b.

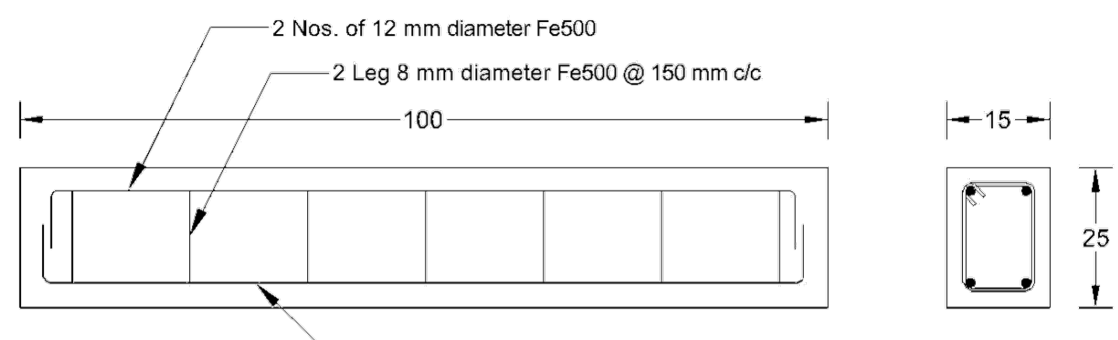

Cross Section

Longitudinal Section

All dimensions are in $\mathrm{cm}$ unless otherwise mentioned.

Figure 4(a). Reinforcement details 


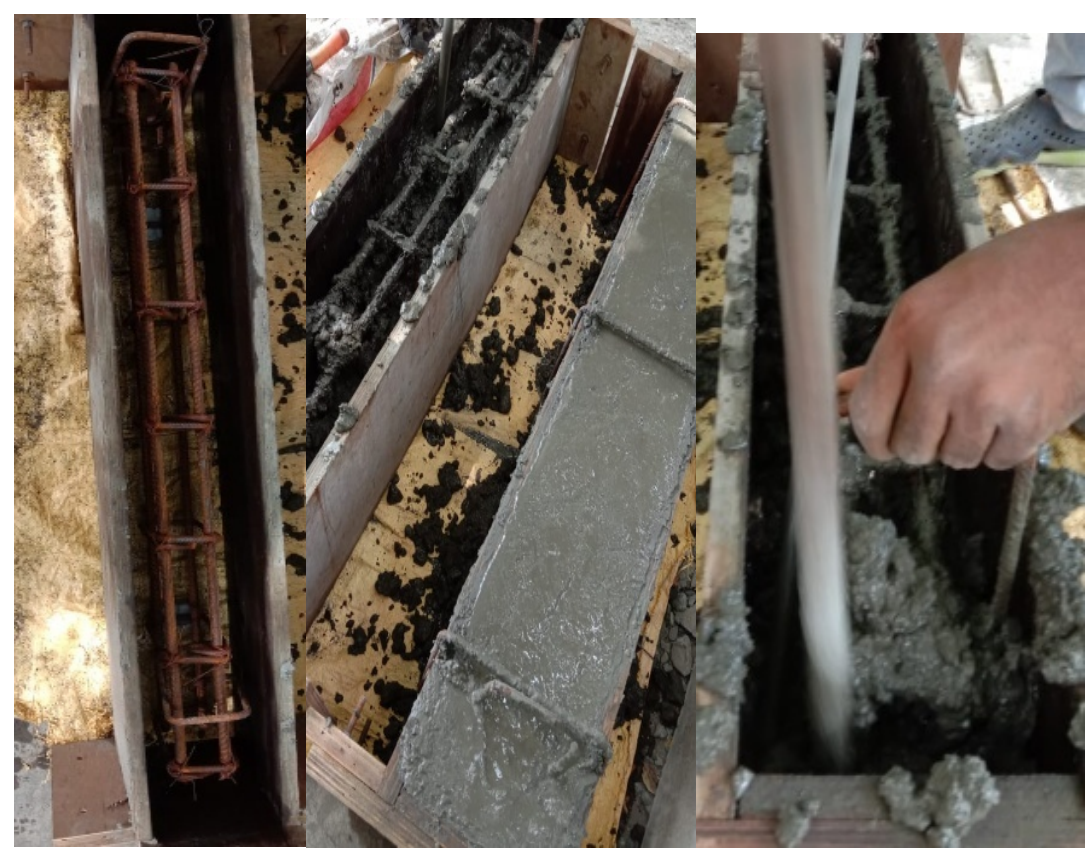

Figure 4(b). Beam reinforcement and casting

\section{Curing}

The casting of beam was done by placing the concrete in to the mould and compacted well for removing the voids. The curing was done for the time period of 28-day in curing tank(Refer with: Figure 5).

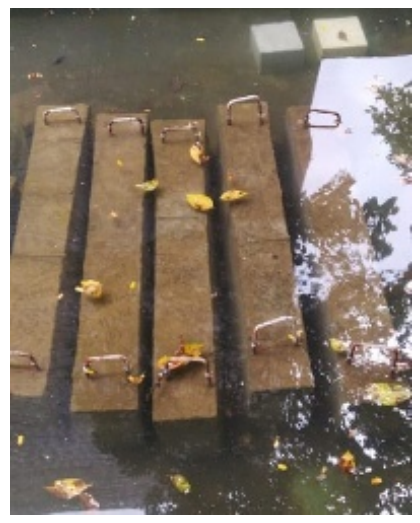

Figure 5. Curing of the specimen

\section{Testing of beams}

For testing of specimen, loading frame was used. The loading frame consists of steel column, beams, hydraulic jack, linear vertical displacement transducer and supports. The loading frame capacity was $750 \mathrm{kN}$. The beam placed over the two-point roller support leaving $50 \mathrm{~mm}$ from the ends of the beam. From the beam span remaining $900 \mathrm{~mm}$ was equally divided and three (Linear Variable Differential Transformer) LVDT were placed to determine the deflection of the beam. 2 numbers of LVDT were placed at $1 / 3^{\text {rd }}$ distance and one LVDT were placed at mid-point(Refer with: Figure 6). Initially the control beams were tested under two-point loading conditions to obtain the initial crack(Refer with: Figure 7.a), then the test was continued to determine the ultimate load carrying capacity of the beam and the type of failure occurred in the beam[14]. 


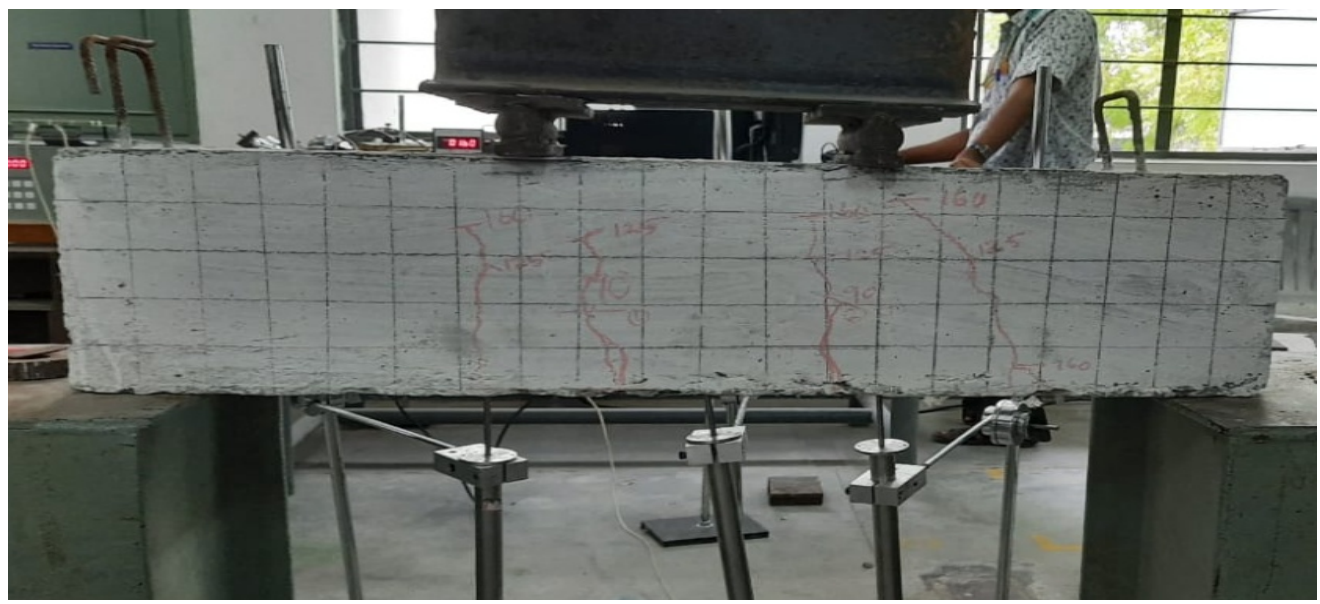

Figure 6. Testing setup of the specimen

\section{Retrofitting of beams and Testing}

The retrofitting on beams was carried out by pasting the fiber mat with the help of resin. The single layer wrapping technique is followed to retrofit the beam. All the beam specimens were loaded to get the initial cracks and then the experiment was stopped. Before wrapping the beam, the surface should be cleaned to make rough surface so that the resin sticks well in the surface of beam. After that the beam was coated with polystyrene resin and the fiber mat was wrapped well (Refer with: Figure 7.b \& 7.c). Similar test was carried out for all the retrofitted beam specimens. From this retrofitted beam test, ultimate load and the maximum deflection of the beam was obtained(Refer with: Figure 7.d\& 7.e).

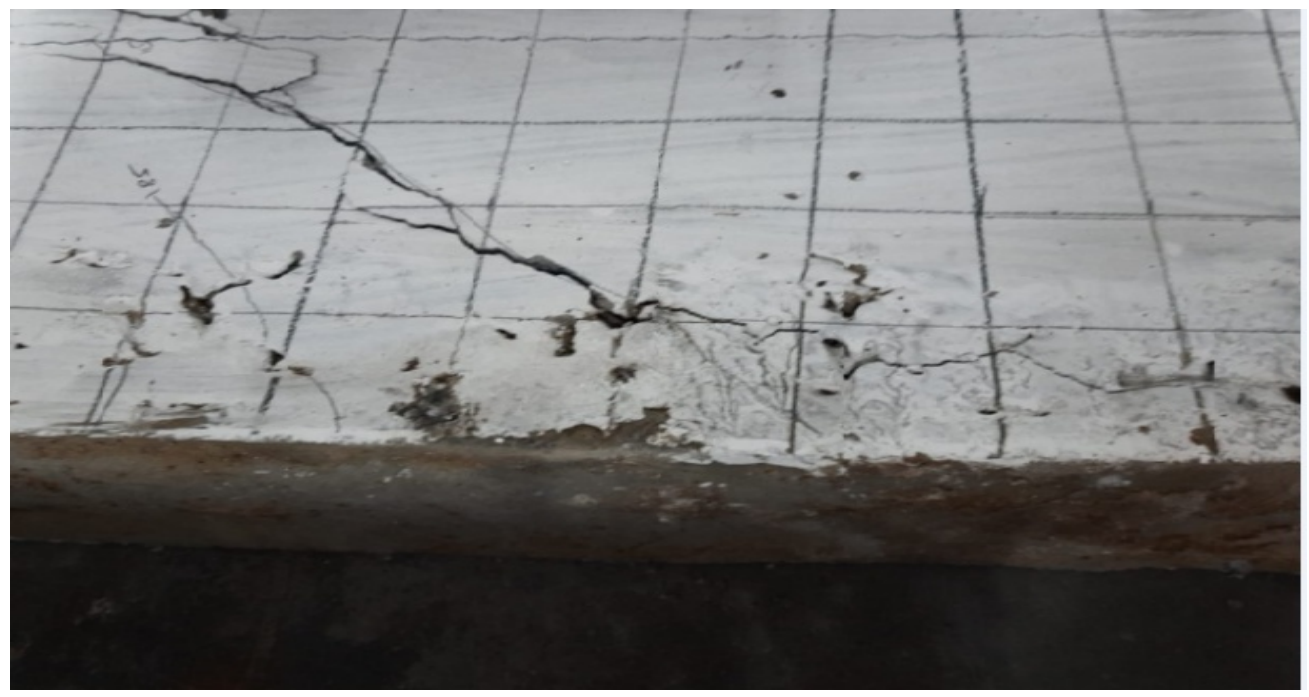

7(a) 


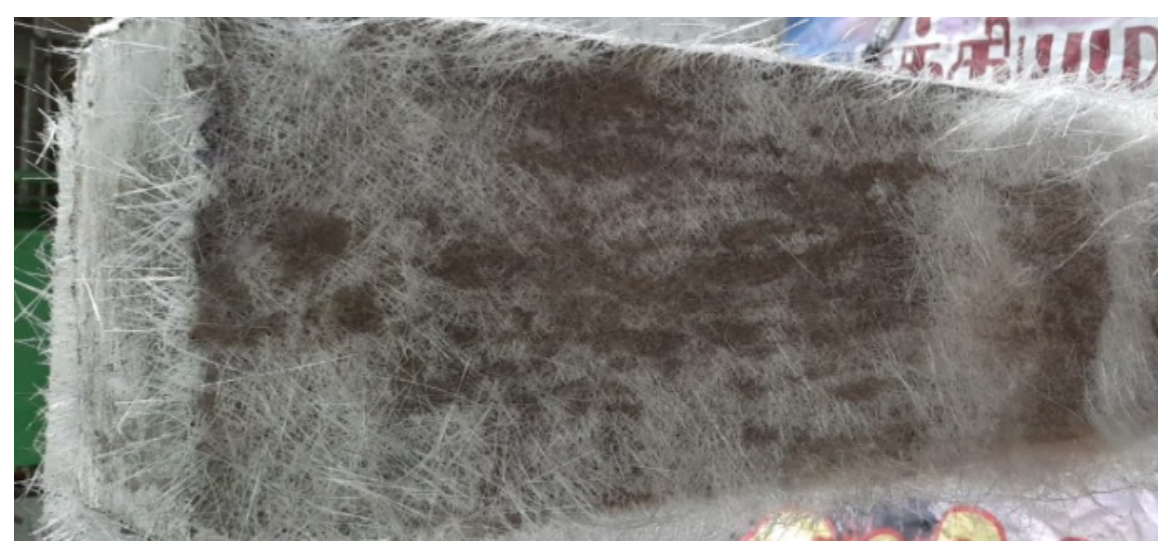

7(b)

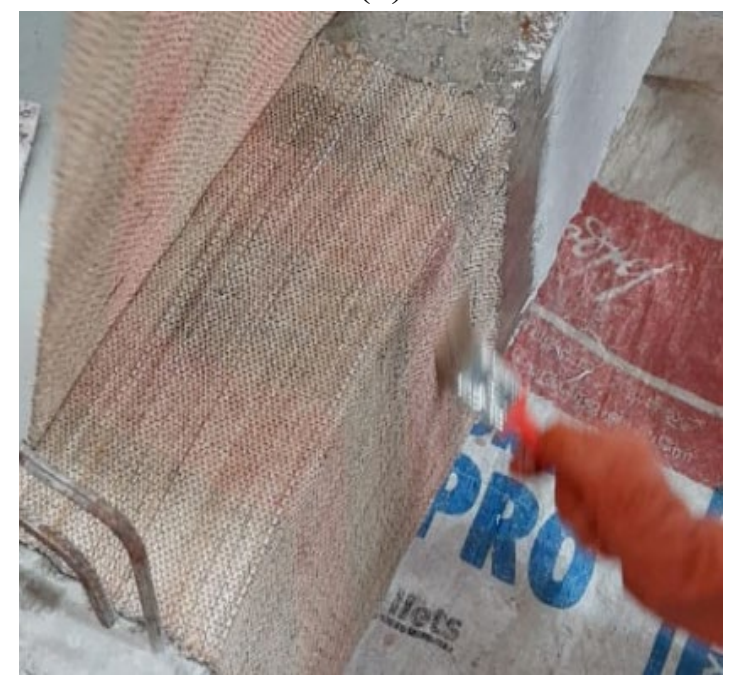

$7(\mathrm{c})$

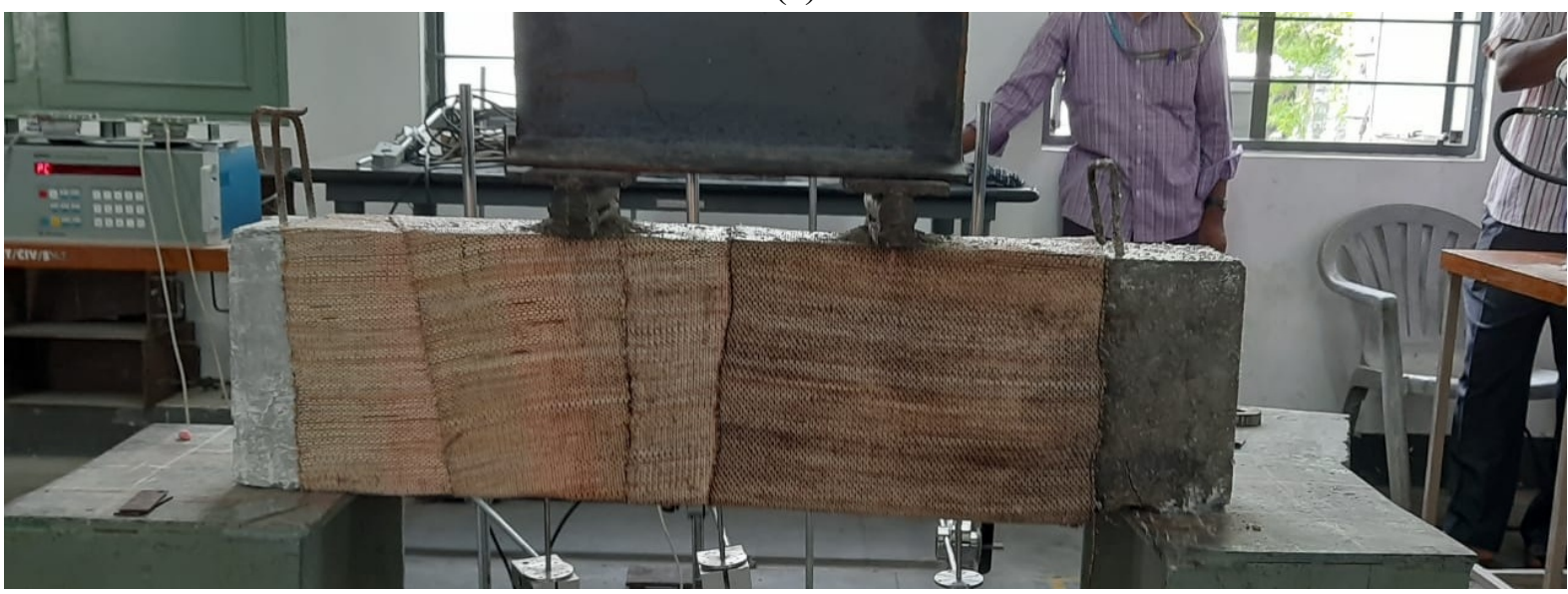

7(d) 


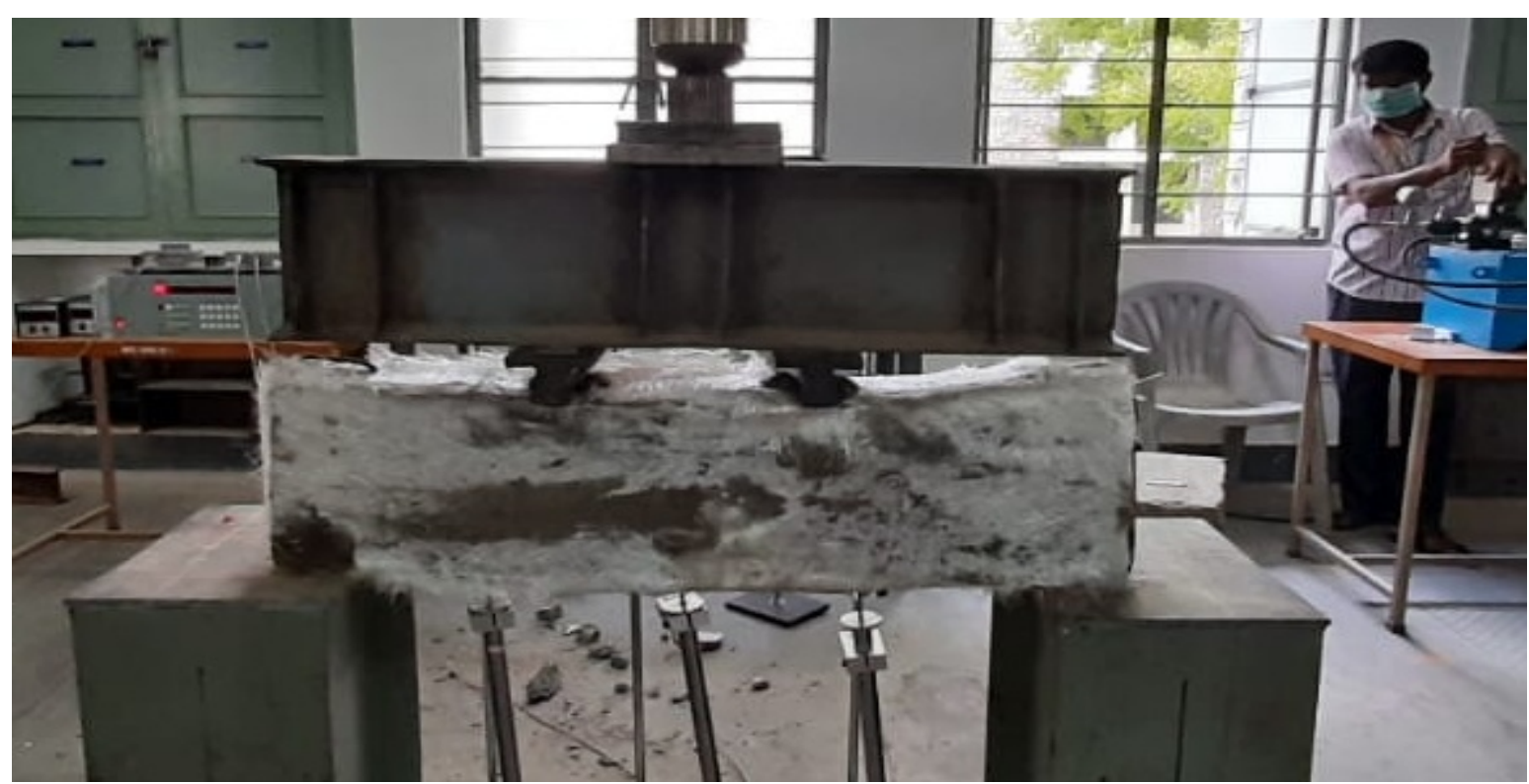

7(e)

Figure 7. (a) Beam with shear cracks, (b) Beam wrapped with glass fiber mat, (c) Beam wrapped with banana fiber mat, (d) Retrofitted banana fiber mat beam testing, (e) Retrofitted glass fiber mat beam testing.

\section{Result and Discussion}

Load carrying capacity of control beam

Table 2 shows the Initial crack load in $\mathrm{kN}$, Ultimate load in $\mathrm{kN}$ and maximum deflection in mm of control beam specimen. Throughout the study beam 1 and beam 2 is subjected to bending failure and shear failure respectively.

Table 2. Control Specimen results

\begin{tabular}{ccccc}
\hline S.no & Type of beam & $\begin{array}{c}\text { Initial crack } \\
\text { load in } \mathbf{~ K N}\end{array}$ & $\begin{array}{c}\text { Ultimate load in } \\
\text { KN }\end{array}$ & $\begin{array}{c}\text { Maximum } \\
\text { deflection in } \mathbf{~ m m}\end{array}$ \\
\hline $\mathbf{1}$ & Control beam 1 & 90.0 & 200 & 3.2 \\
\hline $\mathbf{2}$ & Control beam 2 & 83.5 & 193 & 2.8 \\
\hline
\end{tabular}

Load carrying capacity of retrofitted beam

Concrete beam are subjected to loading until it got initial cracks to replicate the damaged beam at site. Then the beams have retrofitted with wrapping of glass fiber and banana fiber on the periphery of the beam. Table 3 shows the Initial crack load in $\mathrm{kN}$, Ultimate load in $\mathrm{kN}$ and maximum deflection in $\mathrm{mm}$ of retrofitted beam specimen. 
Table 3. Retrofitted Beam Specimens results

\begin{tabular}{ccccc}
\hline S.no & Type of beam & $\begin{array}{c}\text { Ultimate load } \\
\text { inKN }\end{array}$ & $\begin{array}{c}\text { Maximum } \\
\text { deflection in } \mathbf{~ m m}\end{array}$ & $\begin{array}{c}\text { Average deflection } \\
\text { in } \mathbf{~ m m ~}\end{array}$ \\
\hline $\mathbf{1}$ & Glass fiber 1 & 278 & 6.16 & \\
\hline $\mathbf{2}$ & Glass fiber 2 & 255 & 5.84 & 6 \\
\hline $\mathbf{3}$ & Banana fiber 1 & 245 & 3.5 & \multirow{2}{*}{4} \\
\hline $\mathbf{4}$ & Banana fiber 2 & 232 & 4.5 & \\
\hline
\end{tabular}

Wrapping method of retrofitting significantly improved the ultimate load carrying capacity of beams irrespective of the type of fibers. Figure 8 indicates the load versus deflection graph of the control beam. The significant improvement was observed in the glass fiber mat wrapped beam with $39 \%$ and $32 \%$ in their ultimate load carrying capacity of the retrofitted beam(Refer with: Figure 9.a). Whereas only $22.5 \%$ and $20 \%$ increase was observed in banana natural fiber retrofitted beam specimen(Refer with: Figure 9.b).

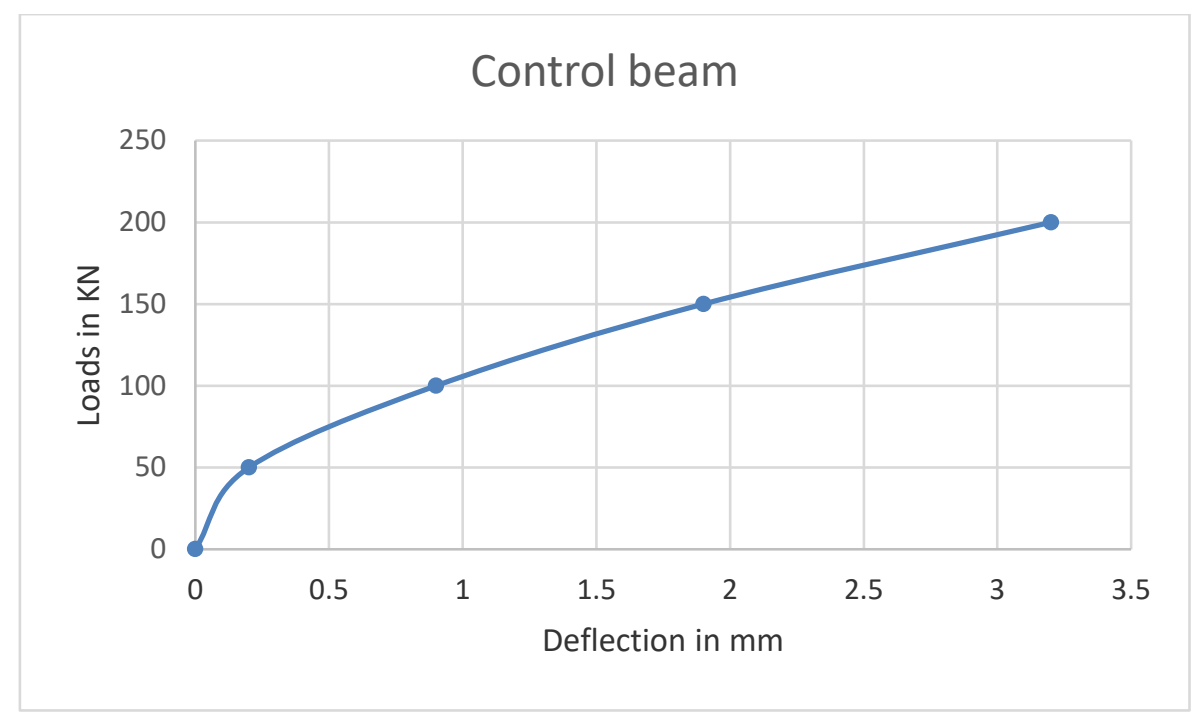

Figure 8.Load vs. Deflection graph of control beam

Even though natural banana fiber wrapping method of retrofitting has not shown the significant butt still it has around $20 \%$ increase in the ultimate load carrying capacity of beam. For sustainable way of retrofitting, banana fiber mat method is adopted.

It is clear from the above graph that the flexibility of the reinforced concrete beam has increased along with its load carrying capacity after wrapping retrofitting. Especially the beam retrofitted with glass fiber's deflection has increased twice than that of the control beam. 


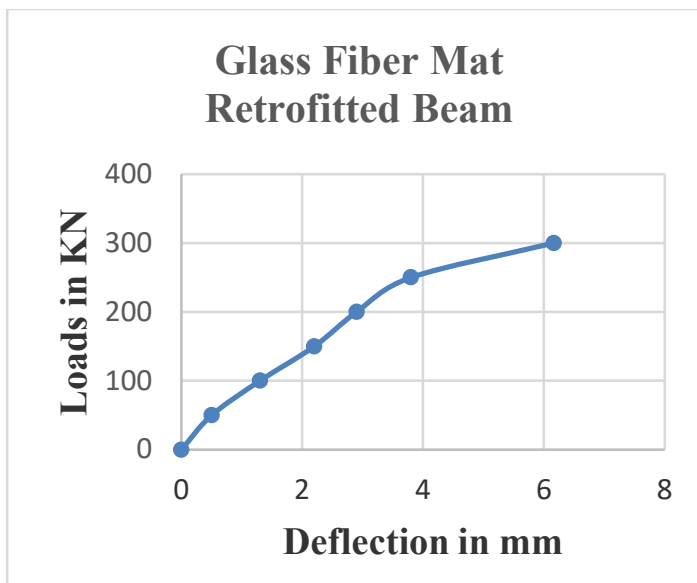

9(a)
Banana Fiber Mat Retrofitted

Beam

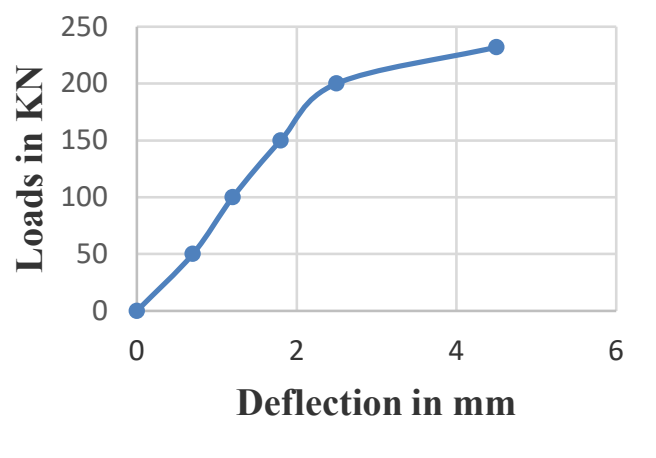

9(b)

Figure 9. Load vs. Deflection graph of retrofitted beam of (a) Glass fiber mat, (b) Banana fiber mat.

\section{Conclusion}

This experimental study has been carried out to ascertain the performance of the wrapping retrofitting method with glass fiber and natural banana fiber mat.

1. This investigation indicates that externally wrapped glass fiber mat and banana fiber mat are an effective method to increase the structural load carrying capacity.

2. Significant increase in ultimate load carrying capacity was found in both the fiber mat retrofitted method, but Ultimate load carrying capacity of glass fiber wrapping retrofitted beam specimen has average of around 35\% increase compared to the conventional beam.

3. Similarly significant improvement in the beam's flexibility was found and especially the beam retrofitted with glass fiber has twice the amount of deflection of control beam before it fails.

4. In allsituations, glass fiber mat wrapping retrofitted method has great performance compared to the natural banana fiber wrapping retrofitted method, but the natural banana fiber mat retrofitting method can be adopted in case of ecofriendly and sustainable situation.

\section{References}

[1] Sandeep G. Sawant, A. B. Sawant, M. B. Kumthekar, Strengthening of R.C.C. Beam-Using Different Glass Fiber, International Journal of Inventive Engineering and Sciences (IJIES) Volume 1, Issue 2(2013).

[2] T.Sirisha, A.V.S Sai kumar, B.Madhanna, Use of Discrete Fiber in Construction, International Journal of Innovative Research in Science, Engineering and Technology,Volume 5, Issue 8 (2016),pp. 15249-15253.

[3] Mohanraj A, Rajendran M, Ramesh A S, Mahalakshmi M, Manoj Prabhakar S, An Experimental Investigation of Eco-Friendly Self-Curing Concrete Incorporated with Polyethylene Glycol, International Advanced Research Journal in Science, Engineering andTechnology, Volume 1, Issue 2 (2014), pp. 85-89.

[4] Rahul Dev Bharti, Prof. Nitesh Khuswaha, Comparative Study on RCC Beams with \& without Carbon Fiber Reinforced Polymer Using Ansys Software, International Journal of Trend in Scientific Research and Development (IJTSRD),Volume 4, Issue 1(2019), pp.478-482. 
[5] P. Arulsivanantham, Experimental Study on usage of Class-E Glass Fiber in the Cement Concrete, International Journal of Engineering Research \& Technology (IJERT), Volume 4, Issue 6 (2015), pp. 116-121. https://doi.org/10.17577/IJERTV4IS060183

[6] K.M. Mini, Rini John Alapatt, Anjana Elizabeth David, Aswathy Radhakrishnan, Minu Maria Cyriac and R. Ramakrishnan, Experimental study on strengthening of R.C beam using glass fiber reinforced composite, Structural Engineering and Mechanics, Volume 50, Number 3 (2014), pp.275-286. https://doi.org/10.12989/sem.2014.50.3.275

[7] T.P. Meikandaan, Dr. A. Ramachandra murthy, Retrofitting of reinforced concrete beams using GFRP overlays, International Journal of Civil Engineering and Technology (IJCIET), Volume 8, Issue 2 (2017), pp.423-439.

[8] Saman Khan, Roohul Abad Khan, Amadur Rahman Khan, Misbahul Islam, Saman Nayal, Mechanical properties of polypropylene fiber reinforced concrete for M25 \& M30m mixes: a comparative study, International Journal of ScientificEngineering and Applied Science (IJSEAS), Volume 1, Issue 6 (2015).

[9] D.N. Shinde, Pudale Yojana M, Nair Veena V, Flexural Behaviour of Reinforced Cement Concrete Beam Wrapped with GFRP sheet, International Journal of Research in Engineering and Technology, Volume 3, Issue 30 (2014), pp.760-763. https://doi.org/10.15623/ijret.2014.0315143

[10] K.Srinivasa Rao, S.Rakesh kumar, A.Laxmi Narayana, Comparison of Performanceof Standard Concrete and Fiber Reinforced Standard Concrete Exposed to Elevated Temperatures, American Journal of Engineering Research (AJER), Volume 2, Issue 3 (2010), pp 20-26.

[11] Kavita S Kene, Vikrant S Vairagade and Satish Sathawane, Experimental Study on Behavior of Steel and Glass Fiber Reinforced Concrete Composites,Bonfring International Journal of Industrial Engineering and Management Science Volume 2, Number 4 (2012), pp. 125-130. https://doi.org/10.9756/BIJIEMS.1617

[12] T.P. Meikandaan, Dr. A. Ramachandra murthy, Retrofitting of Reinforced Concrete Beams using GFRP Overlays, International Journal of Civil Engineering and Technology (IJCIET), Volume 8, Issue 2 (2017), pp.423-439.

[13] Nanditha Mandava, Kallempudi Murali, M. Srinadh Reddy, M Narendranatha Reddy, Investigation of Reinforced Concrete Beams by Incorporating Polypropylene Fiber Reinforced Polymer Composites, International Journal of Civil Engineering and Technology (IJCIET), Volume 9, Issue 1, (2018), pp. 423-430.

[14] IS: 516-1959 (2006),Indian Standard Methods of Tests for Strength of Concrete, Bureau of Indian Standards, New Delhi, India.

[15] S. Shankarananth, B. Jaivignesh, Experimental Study on the use of Glass Powder, GGBS \& Perlite in Flyash Bricks,International Journal of AdvancedResearch,Volume 4 (2016), pp 1381-1387. https://doi.org/10.21474/IJAR01/292

[16] IS:10262 (2009),Concrete Mix Proportioning-Guidelines, Bureau of Indian Standards, New Delhi, India. 